\section{Petunia (Petunia Xhybrida) Cultivars Vary in Silicon Accumulation and Distribution}

\author{
Jennifer K. Boldt \\ USDA-ARS Application Technology Research Unit, 2801 W. Bancroft Street \\ Mail Stop 604, Toledo, OH 43606
}

\author{
James E. Altland \\ USDA-ARS Application Technology Research Unit, 1680 Madison Avenue, \\ Wooster, OH 44691
}

Additional index words. floriculture, plant nutrition, potassium silicate

\begin{abstract}
Silicon (Si) is a plant-beneficial element that can alleviate the effects of abiotic and biotic stress. Plants are typically classified as $\mathrm{Si}$ accumulators based on foliar $\mathrm{Si}$ concentrations ( $\geq 1 \%$ Si on a dry weight basis for accumulators). By this definition, most greenhouse-grown ornamentals are low Si accumulators. However, plants that accumulate low foliar Si concentrations may still accumulate high Si concentrations elsewhere in the plant. Additionally, screening cultivars for variability in Si uptake has not been investigated for low $\mathrm{Si}$ accumulator species. Therefore, the objective of this study was to assess cultivar variability in Si accumulation and distribution in petunia (Petunia $\times$ hybrida). Eight cultivars (Supertunia Black Cherry, Supertunia Limoncello, Supertunia Priscilla, Supertunia Raspberry Blast, Supertunia Royal Velvet, Supertunia Sangria Charm, Supertunia Vista Silverberry, and Supertunia White Improved) were grown in a commercial peat-based soilless substrate under typical greenhouse conditions. They were supplemented with either $2 \mathrm{~mm}$ potassium silicate $(+\mathrm{Si})$ or potassium sulfate (-Si) at every irrigation. Silicon supplementation increased leaf dry mass $(4.5 \%)$ but did not affect total dry mass. In plants not receiving Si supplementation, leaf $\mathrm{Si}$ ranged from 243 to $1295 \mathrm{mg} \cdot \mathrm{kg}^{-1}$, stem Si ranged from 48 to $380 \mathrm{mg} \cdot \mathrm{kg}^{-1}$, flower Si ranged from 97 to $437 \mathrm{mg} \cdot \mathrm{kg}^{-1}$, and root $\mathrm{Si}$ ranged from 103 to $653 \mathrm{mg} \cdot \mathrm{kg}^{-1}$. Silicon supplementation increased Si throughout the plant, but most predominantly in the roots. Leaf $\mathrm{Si}$ in the $2 \mathrm{~mm}$ Si treatment ranged from 1248 to $3541 \mathrm{mg} \cdot \mathrm{kg}^{-1}$ (173\% to $534 \%$ increase), stem Si ranged from 195 to $654 \mathrm{mg} \cdot \mathrm{kg}^{-1}$ (72\% to $376 \%$ increase), flower Si ranged from 253 to $1383 \mathrm{mg} \cdot \mathrm{kg}^{-1}\left(74 \%\right.$ to $1082 \%$ increase), and root Si ranged from 4018 to $10,457 \mathrm{mg} \cdot \mathrm{kg}^{-1}$ $(593 \%$ to $9161 \%$ increase). The large increase in root Si following supplementation shifted Si distribution within plants. In nonsupplemented plants, it ranged from $51.2 \%$ to $\mathbf{7 6 . 8} \%$ in leaves, $8.2 \%$ to $40.2 \%$ in stems, $2.8 \%$ to $23.8 \%$ in flowers, and $1.2 \%$ to $13.8 \%$ in roots. In Si-supplemented plants, it ranged from $63.5 \%$ to $67.7 \%$ in leaves, $10.5 \%$ to $22.6 \%$ in roots, $9.4 \%$ to $17.7 \%$ in stems, and $1.6 \%$ to $9.6 \%$ in flowers. This study indicates that petunia, a low foliar $\mathrm{Si}$ accumulator, can accumulate appreciable quantities of $\mathrm{Si}$ in roots when provided supplemental $\mathrm{Si}$.
\end{abstract}

Silicon $(\mathrm{Si})$ is associated with many positive physiological responses in plants (Kamenidou et al., 2008, 2010; Liang et al., 1996; Ma, 2004; Ma and Yamaji, 2006; Romero-Aranda et al., 2006; Savant et al., 1999). It is classified as a beneficial element and has been shown to mitigate the impacts of

\footnotetext{
Received for publication 30 Sept. 2020. Accepted for publication 4 Dec. 2020.

Published online 19 January 2021.

Mention of trade names or commercial products in this publication is solely for the purpose of providing specific information and does not imply recommendation or endorsement by the U.S. Department of Agriculture (USDA). The USDA is an equal opportunity provider and employer.

J.K.B. is the corresponding author. E-mail: jennifer. boldt@usda.gov.

This is an open access article distributed under the CC BY-NC-ND license (https://creativecommons. org/licenses/by-nc-nd/4.0/).
}

many biotic and abiotic stresses, including fungal pathogens (Chain et al., 2009; Datnoff et al., 1997; Guével et al., 2007; Menzies et al., 1992), herbivory (Massey et al., 2006; Reynolds et al., 2009), drought (Hattori et al., 2005; Zhu and Gong, 2014), salt stress (Liang et al., 1996; Romero-Aranda et al., 2006), heat stress (Agarie et al., 1998), chilling injury (He et al., 2010; Liang et al., 2008), nutrient deficiencies (Ma, 2004), and heavy metal toxicity (Frantz et al., 2011). The use of soilless substrates or hydroponic systems in greenhouse production has resulted in low $\mathrm{Si}$ availability for many plants. Silicon fertilization in greenhouse production is becoming more widespread as its role in plant health is better understood (Voogt and Sonneveld, 2001; personal observation).

Foliar Si concentration can range from $0.1 \%$ to $10 \%$ on a dry mass basis (Epstein, 1999). Silicon accumulators are classified as plants that attain $\geq 1 \% \mathrm{Si}$ on a dry mass basis (i.e., 10,000 mg. $\mathrm{kg}^{-1}$ ) (Epstein, 1999; Ma et al., 2001). Many species within Poaceae are $\mathrm{Si}$ accumulators, including important agronomic crops such as barley (Hordeum vulgare L.), corn (Zea mays L.), oats (Avena sativa L.), rice (Oryza sativa L.), sugarcane (Saccharum officinarum L.), and wheat (Triticum aestivum L.) (Deren et al., 1992, 1993; Handreck and Jones, 1968; Hodson et al., 2005; Jones and Handreck, 1967; Lanning et al., 1980; Ma et al., 2007; Murozuka et al., 2015; Savant et al., 1999). Some species within the horticulturally important Cucurbitaceae [cucumber (Cucumis sativus L.) squash and pumpkin (Cucurbita spp.)] and Asteraceae [sunflower (Helianthus annuus L.) and zinnia (Zinnia elegans L.)] are also Si accumulators (Frantz et al., 2010). However, most greenhouse-grown ornamentals are low $\mathrm{Si}$ accumulators. Frantz et al. (2010) quantified the foliar Si concentration of 48 horticultural crops, grown hydroponically in a modified Hoagland's solution amended with $1 \mathrm{~mm} \mathrm{Si}$, and they found it to range between $102 \mathrm{mg} \cdot \mathrm{kg}^{-1}$ [ornamental tobacco (Nicotiana sylvestris Speg. \& Comes.)] and $12,682 \mathrm{mg} \cdot \mathrm{kg}^{-1} \mathrm{Si}$ (zinnia).

Plant Si concentration can vary with environmental conditions, substrate (soil, soilless, or hydroponic), nutrients supplied, plant tissue, species, and genotype. Genotypic variation in Si concentration has been reported for barley grain (Ma et al., 2003), rice (Deren et al., 1992; Ma et al., 2007; Wu et al., 2006), sugarcane (Deren et al., 1993), wheat straw (Murozuka et al., 2015), bamboo (Collin et al., 2012), finger millet [Eleusine coracana (L.) Gaertn.] (Sandhya et al., 2011), and calibrachoa (Calibrachoa $\times$ hybrida Cerv.) (Mattson and Leatherwood, 2010). However, there is little published research on the distribution of $\mathrm{Si}$ in ornamental plants, let alone cultivar variation in Si distribution. In species where Si distribution has been documented, it was not uniform within the plant. Rice grown in nutrient solution with $150 \mathrm{ppm} \mathrm{SiO}_{2}$ averaged $9800 \mathrm{mg} \cdot \mathrm{kg}^{-1} \mathrm{Si}$ in roots, 57,000 $\mathrm{mg} \cdot \mathrm{kg}^{-1}$ in leaf sheaths, and $63,000 \mathrm{mg} \cdot \mathrm{kg}^{-1}$ in leaf blades, as calculated from values reported as $\% \mathrm{SiO}_{2}$ on a dry matter basis (Yoshida et al., 1962). In oat, Si ranged from $280 \mathrm{mg} \cdot \mathrm{kg}^{-1}$ in caryopses to $36,000 \mathrm{mg} \cdot \mathrm{kg}^{-1}$ in inflorescences, with over $40 \%$ of total aboveground $\mathrm{SiO}_{2}$ localized in inflorescences (Jones and Handreck, 1967). Kamenidou et al. (2008) compared the effects of different sources of $\mathrm{Si}$ supplementation on tissue $\mathrm{Si}$ concentration of sunflower 'Ring of Fire' grown in a peat-based soilless substrate, and while tissue concentrations were not compared within a treatment, reported leaf $\mathrm{Si}$ concentrations (4900 to $15,300 \mathrm{mg} \cdot \mathrm{kg}^{-1}$ ) were greater than flowers (3800 to 5100 $\mathrm{mg} \cdot \mathrm{kg}^{-1}$ ) or stems (2900 to $4200 \mathrm{mg} \cdot \mathrm{kg}^{-1}$ ).

The use of Si fertilization historically has been limited in greenhouse production, partially because its many benefits were not known and because most greenhouse-grown crops are low Si accumulators. There has been debate as to whether Si supplementation is beneficial to low $\mathrm{Si}$ accumulators, because 
they do not accumulate high foliar concentrations of Si (Ma et al., 2001; Mitani and Ma, 2005). However, Si can provide benefit in both a structural capacity and as a signaling compound (Fauteux et al., 2006), and therefore, low Si accumulators may still benefit from Si supplementation, especially following imposition of a stress. For example, adding $\mathrm{Si}$ to the hydroponic nutrient solution delayed Tobacco ringspot virus (TSRV) symptom formation and reduced symptomatic leaf area in tobacco (Nicotiana tabacum L.), a low Si accumulator (Zellner et al., 2011). Silicon ameliorated copper $(\mathrm{Cu})$ toxicity in arabidopsis [Arabidopsis thaliana L. (Heynh.)] (Li et al., 2008) and snapdragon (Antirrhinum majus L.) (Frantz et al., 2011), also low $\mathrm{Si}$ accumulators. Knowledge of $\mathrm{Si}$ distribution in plants, as well as variability amongst cultivars, may be critical if using $\mathrm{Si}$ to mitigate plant stresses that are tissuespecific. For example, botrytis (Botrytis cinerea) typically attacks flowers and leaves, whereas pythium (Pythium ultimum) causes root rot. If, for instance, flowers of one or more genotypes were found to contain appreciable quantities of $\mathrm{Si}$, studies could investigate whether the accumulation provides protection and offers growers a nonpesticide alternative to include in their pest management rotation.

Petunia (Petunia $\times$ hybrida Hort. Vilm.Andr.) is a popular bedding plant. In 2014, it accounted for $12 \%$ of the annuals sold in the United States, with a value of almost \$263 million (U.S. Department of Agriculture, National Agricultural Statistics Service, 2015). Despite its popularity, it presents some production and shipping challenges to growers, including flower sensitivity to botrytis infection. Petunia is a low Si accumulator, and its foliar response to $\mathrm{Si}$ supplementation has been evaluated previously. Frantz et al. (2008) observed 193 $\mathrm{mg} \cdot \mathrm{kg}^{-1} \mathrm{Si}$ in petunia 'White Madness' grown hydroponically in a nutrient solution amended with $2 \mathrm{~mm}$ potassium silicate. Mattson and Leatherwood (2010) observed $506 \mathrm{mg} \cdot \mathrm{kg}^{-1} \mathrm{Si}$ in petunia 'Cascadias Cherry Spark' grown in a peat-based soilless substrate and supplemented with weekly drenches of $3.57 \mathrm{~mm}$ potassium silicate. Boldt et al. (data not published) detected, on average, $1045 \mathrm{mg} \cdot \mathrm{kg}^{-1} \mathrm{Si}$ in petunia 'Dreams Pink' grown in a peat-based substrate and supplemented with $2 \mathrm{~mm}$ potassium silicate. In another study, 'Dreams Pink' accumulated $2036 \mathrm{mg} \cdot \mathrm{kg}^{-1}$ when grown in a peat-based substrate amended with $20 \%$ (by volume) parboiled rice hulls (Boldt et al., 2018). In all these studies, petunias supplemented with $\mathrm{Si}$ had greater foliar Si accumulation than plants not receiving supplemental $\mathrm{Si}$. This suggests that even though petunia is a low Si accumulator, 1) it has the capacity to accumulate $\mathrm{Si}$ in leaves following Si supplementation, and 2) cultivars vary in foliar Si concentration. Therefore, the objective of this study was to quantify Si accumulation and distribution in the leaves, stems, flowers, and roots of eight petunia cultivars to better understand genotypic variation in how this crop accumulates and distributes $\mathrm{Si}$.

\section{Materials and Methods}

Rooted liners of eight petunia cultivars ['Supertunia Black Cherry' (Black Cherry), 'Supertunia Limoncello' (Limoncello), 'Supertunia Priscilla' (Priscilla), 'Supertunia Raspberry Blast' (Raspberry Blast), 'Supertunia Royal Velvet' (Royal Velvet), 'Supertunia Sangria Charm' (Sangria Charm), 'Supertunia Vista Silverberry' (Silverberry), and 'Supertunia White Improved' (White)] in 72-count cell trays were received from a commercial greenhouse (Pleasant View Gardens, Louden, NH) on 12 Nov. 2015. They were transplanted on 16 Nov. 2015 into 11.5$\mathrm{cm}$ diameter pots filled with a peat-based soilless substrate (LB-2; SunGro Horticulture, Agawam, MA). Plants were grown in a glass-glazed greenhouse (Toledo, $\mathrm{OH}$ ). Air temperature set points were $22{ }^{\circ} \mathrm{C}$ day $/ 18^{\circ} \mathrm{C}$ night. Supplemental irradiance was provided by $1000-W$ high pressure sodium lamps between 0700-1900 HR when benchtop ambient irradiance was less than $300 \mu \mathrm{mol} \cdot \mathrm{m}^{-2} \cdot \mathrm{s}^{-1}$ photosynthetic photon flux density (PPFD). Air temperature and $P P F D$ were measured with aspirated thermocouples and quantum sensors (MQ-200; Apogee Instruments, Logan, UT), respectively, and recorded every 15 min using a Campbell Scientific datalogger (CR10X; Campbell Scientific, Logan, UT). Mean air temperatures were $21.4 \pm$ $0.2{ }^{\circ} \mathrm{C}$ day $/ 18.1 \pm 0.3{ }^{\circ} \mathrm{C}$ night, and mean daily light integral (DLI) was $6.4 \pm 0.8$ $\mathrm{mol} \cdot \mathrm{m}^{-2} \cdot \mathrm{d}^{-1}$.

The base fertilizer solution was $20 \mathrm{~N}-$ 4.4P-16.6K (Jacks 20-10-20; JR Peters, Inc., Allentown, PA) at a concentration of $150 \mathrm{mg} \cdot \mathrm{L}^{-1} \mathrm{~N}$. It was amended with either $2 \mathrm{~mm}$ potassium silicate $(+\mathrm{Si})$ or $2 \mathrm{~mm}$ potassium sulfate $(-\mathrm{Si})$ as an offset to balance potassium application. Silicic acid and potassium hydroxide (KOH) (Fisher Scientific, Fair Lawn, NJ) were dissolved to formulate the potassium silicate solution. The $\mathrm{pH}$ of the two nutrient solutions was adjusted to $5.5 \pm$ 0.1 using $\mathrm{KOH}$ or hydrochloric acid $(\mathrm{HCl})$. Ultra-purified water (18 $\mathrm{M} \Omega$ ) was used to minimize Si contamination.

Plants were irrigated as needed with nutrient solution. The volume applied at each irrigation increased from 50 to $200 \mathrm{~mL}$ as plant size increased. Not all cultivars were irrigated at the same frequency due to differences in plant size. An equal volume of nutrient solution was applied to all plants, across both Si treatments, within a cultivar when irrigated. Containers were irrigated to near-container capacity, and a saucer was placed beneath each pot to catch any runoff (which infrequently occurred) and to allow it to be reabsorbed by the substrate. The volume of nutrient solution applied at each irrigation was recorded for each cultivar so that total $\mathrm{Si}$ applied could later be calculated. Plants were harvested $\approx 10$ weeks after transplant, once a sufficient number of flowers had opened to provide enough dry mass for an analysis of $\mathrm{Si}$ concentration. This was $\approx 30$ flowers for all cultivars except Priscilla (a double-flowered cultivar), based on a preharvest assessment of mean flower dry mass of flowers collected from additional (nonexperimental) plants of these cultivars.

The pour-through technique (LeBude and Bilderback, 2009) was conducted, and a 50 $\mathrm{mL}$ sample of leachate was collected from each pot. Leachate samples were immediately refrigerated at $4{ }^{\circ} \mathrm{C}$ until the following day, and $\mathrm{pH}$ and electrical conductivity (EC) was measured (HANNA HI9814 GroPro; Hanna Instruments, Woonsocket, RI) once samples had returned to room temperature. Samples were then frozen until nutrient analyses could be conducted. After thawing, the leachates were filtered (Whatman \#2 filter paper; Whatman Ltd., Kent, UK). To determine Si concentration, $9.5 \mathrm{~mL}$ of $2.1 \% \mathrm{KOH}$ was added to a $0.5 \mathrm{~mL}$ aliquot of leachate, and the solution was analyzed using inductively coupled plasma-optical emission spectroscopy (ICP-OES; iCAP 6300 Duo, Thermo Electron Corp., Waltham, MA).

Aboveground tissue was separated into leaves, stems (including stems, petioles, sepals, and immature flower buds), and flowers (senesced flowers, open flowers, and buds with visible petal coloration). Roots were washed in $18 \mathrm{M} \Omega$ water and gently separated from the soilless substrate. Each tissue type was separately dipped into acidified water $(0.1 \mathrm{M} \mathrm{HCl})$, rinsed in $18 \mathrm{M} \Omega$ water, placed in a paper bag, dried in a forced-air oven at $60{ }^{\circ} \mathrm{C}$ for a minimum of $3 \mathrm{~d}$, and weighed for dry mass. They were ground into a fine powder using a mortar and pestle (roots, leaves, and flowers) or coffee grinder (stems).

To analyze for Si concentration, $\approx 0.15 \mathrm{~g}$ of dry tissue was weighed and placed in a Teflon vessel. Three milliliters of 7.5 M KOH was added, and the samples were heated in a programmable microwave (MARS6; CEM Corp., Matthews, NC). The temperature was ramped up to $200{ }^{\circ} \mathrm{C}$ over $15 \mathrm{~min}$., maintained at $200{ }^{\circ} \mathrm{C}$ for $15 \mathrm{~min}$., then cooled to room temperature. After cooling, $2 \mathrm{~mL}$ of hydrogen peroxide was added. Solutions were reheated to $200{ }^{\circ} \mathrm{C}$ and maintained for an additional $5 \mathrm{~min}$. After cooling, $10 \mathrm{~mL}$ of $18 \mathrm{M} \Omega$ water was added, and the solutions were filtered (Whatman \#2). Finally, a $1 \mathrm{~mL}$ aliquot of solution was diluted with $9 \mathrm{~mL}$ of $18 \mathrm{M} \Omega$ water and analyzed using ICP-OES.

Foliar nitrogen $(\mathrm{N})$ was determined by measuring $\approx 2.5 \mathrm{mg}$ of dry tissue into tin capsules (Costech Analytical, Valencia, CA) and then analyzing with a $\mathrm{CHN}$ analyzer (vario MICRO cube; Elementar, Hanau, Germany). For all other elements (except N and $\mathrm{Si}$ ), $\approx 0.25 \mathrm{~g}$ of dry tissue was placed in a Teflon vessel, and $5 \mathrm{~mL}$ of nitric acid was added. Samples were heated in a programmable microwave as described above for $\mathrm{Si}$ quantification with the following exceptions: $1.5 \mathrm{~mL}$ of hydrogen peroxide was added after the first heating stage, and $12 \mathrm{~mL}$ of $18 \mathrm{M} \Omega$ water was added after the second heating stage. After cooling, solutions were filtered. 
A $1.3 \mathrm{~mL}$ aliquot of solution was diluted with $8.7 \mathrm{~mL} 18 \mathrm{M} \Omega$ water and analyzed using ICP-OES.

To compare the total amount of Si taken up and stored within the plants, Si content (mg per plant) for leaves, flowers, stems, and roots of each plant was calculated by multiplying tissue dry mass (converted to kg per plant) by tissue $\mathrm{Si}$ concentration $\left(\mathrm{mg} \cdot \mathrm{kg}^{-1}\right)$. Using the calculated values for Si content, Si distribution was determined individually for each plant as the percent of total plant $\mathrm{Si}$ content present in each tissue.

The percent of applied $\mathrm{Si}$ incorporated by each cultivar was calculated. As described above, the volume of nutrient solution supplied to each cultivar was recorded; multiplying the total volume applied (3.2 to $4.6 \mathrm{~L}$ ) by the Si concentration of the nutrient solution $\left(2 \mathrm{~mm} \mathrm{Si}=56 \mathrm{mg} \cdot \mathrm{L}^{-1}\right)$ yielded the total $\mathrm{Si}$ (in mg) supplied to each cultivar. Next, mean plant Si content (in mg per plant) of the $2 \mathrm{~mm}$ treatment for each cultivar was divided by the total Si supplied (mg) to that cultivar, to calculate the fraction of total Si supplied that had been incorporated into the plants (expressed on a percent basis). This, however, did not account for background $\mathrm{Si}$ present (e.g., in the substrate, base fertilizer, or starting plant material). Therefore, a second calculation was made that subtracted the mean $\mathrm{Si}$ content of the $0 \mathrm{~mm}$ treatment of each cultivar from the mean Si content of the $2 \mathrm{~mm}$ treatment before dividing by the total $\mathrm{Si}$ supplied. Means rather than individual values were used because the 0 and $2 \mathrm{~mm}$ experimental replicates were arranged in a randomized (unpaired) arrangement.

The treatment design was a $2 \times 8$ factorial arrangement with two Si concentrations and eight cultivars. The experimental design was completely randomized with 10 single plant replicates per treatment. Data were subjected to analysis of variance using SAS 9.3 (PROC GLM; SAS Institute Inc., Cary, NC). Means were separated with Tukey's honest significant difference test $(\alpha=0.05)$.

\section{Results}

Leachate $\mathrm{pH}, \mathrm{EC}$, and Si. Leachate $\mathrm{pH}$ averaged $5.61 \pm 0.05$ to $6.02 \pm 0.06$ for plants receiving $0 \mathrm{~mm} \mathrm{Si}$, and $5.81 \pm 0.08$ to $6.17 \pm$ 0.07 for plants receiving $2 \mathrm{~mm} \mathrm{Si}$ (mean $\pm \mathrm{SE}$; Table 1). Despite a cultivar $\times \mathrm{Si}$ interaction $(P=0.0005), \mathrm{pH}$ between the 0 and $2 \mathrm{~mm} \mathrm{Si}$ treatments did not differ for any of the eight cultivars evaluated. Leachate EC concentrations ranged between $2.92 \pm 0.16$ and $3.81 \pm$ $0.14 \mathrm{mS} \cdot \mathrm{cm}^{-1}$ when provided $0 \mathrm{~mm} \mathrm{Si}$ and between $1.50 \pm 0.09$ and $3.81 \pm 0.21 \mathrm{mS} \cdot \mathrm{cm}^{-1}$ when provided $2 \mathrm{~mm} \mathrm{Si}$ (Table 1). All cultivars, except Black Cherry, had higher EC concentrations when fertilized with $0 \mathrm{mM} \mathrm{Si}$ compared with $2 \mathrm{~mm} \mathrm{Si}$.

Leachate $\mathrm{Si}$ averaged $0.73 \pm 0.09$ to $2.90 \pm 0.23 \mathrm{mg} \cdot \mathrm{L}^{-1}$ for plants grown without supplemental Si (Table 1). Low background levels of Si likely released from the sphagnum peatmoss (Frantz et al., 2010). Leachate $\mathrm{Si}$ averaged $25.68 \pm 1.20$ to $37.28 \pm 1.83$ $\mathrm{mg} \cdot \mathrm{L}^{-1}$ for plants supplied $2 \mathrm{~mm}$ Si (Table 1 ). As expected, all cultivars had higher leachate $\mathrm{Si}$ when supplemented with $2 \mathrm{~mm} \mathrm{Si}$, compared with nonsupplemented plants.

Si concentration. All cultivars had higher leaf, stem, flower, and root Si concentrations when supplemented with $2 \mathrm{~mm} \mathrm{Si}$, and thus the interactions observed (Table 1) resulted from differences in the magnitude of enhancement resulting from $\mathrm{Si}$ supplementation. Leaf Si concentration ranged between $243 \pm 27$ and $1295 \pm 396 \mathrm{mg} \cdot \mathrm{kg}^{-1}$ in plants fertilized with $0 \mathrm{~mm} \mathrm{Si}$, and between $1248 \pm$
64 and $3541 \pm 339 \mathrm{mg} \cdot \mathrm{kg}^{-1}$ in plants fertilized with $2 \mathrm{~mm} \mathrm{Si}$. The percent increase in leaf Si concentration with supplemental Si ranged from $173 \%$ in Limoncello to $534 \%$ in Raspberry Blast.

Stem Si concentration ranged between $48 \pm$ 8 and $380 \pm 76 \mathrm{mg} \cdot \mathrm{kg}^{-1}$ in the $0 \mathrm{~mm} \mathrm{Si}$ treatment, and between $195 \pm 20$ and $654 \pm$ $54 \mathrm{mg} \cdot \mathrm{kg}^{-1}$ in the $2 \mathrm{~mm}$ treatment (Table 1). Stem Si concentration increased $72 \%$ to $376 \%$ with $\mathrm{Si}$ supplementation. Five cultivars had enhanced stem Si concentration when fertilized with $2 \mathrm{~mm}$ Si (Black Cherry, Limoncello, Priscilla, Royal Velvet, and White), while the other three cultivars (Raspberry Blast, Sangria Charm, and Silverberry) had similar stem $\mathrm{Si}$ concentrations in both treatments. The lack of a statistically significant increase in those three cultivars was due to plant-to-plant variability and the choice of a conservative post-hoc test for multiple comparisons.

Floral (petal, pistil, and stamen) Si concentration ranged between $97 \pm 31$ and $437 \pm$ $96 \mathrm{mg} \cdot \mathrm{kg}^{-1}$ in nonsupplemented plants, and between $253 \pm 22$ and $1383 \pm 543 \mathrm{mg} \cdot \mathrm{kg}^{-1}$ in Si-supplemented plants (Table 1). Silicon concentration increased $74 \%$ to $1082 \%$ in flowers of plants supplied $2 \mathrm{~mm} \mathrm{Si}$. However, Black Cherry was the only cultivar to have a significant increase in floral Si concentration. This was likely due, in part, to large plant-toplant variability within treatments.

Root $\mathrm{Si}$ concentration ranged between $103 \pm 14$ and $653 \pm 169 \mathrm{mg} \cdot \mathrm{kg}^{-1}$ in nonsupplemented plants, and between $4018 \pm 983$ and $10,457 \pm 1270 \mathrm{mg} \cdot \mathrm{kg}^{-1}$ in Si-treated plants (Table 1). All cultivars had a higher Si concentration in the $2 \mathrm{~mm}$ Si treatment, compared with the $0 \mathrm{~mm}$ Si treatment, and the percent increase was $593 \%$ to $9161 \%$ in Si-treated plants.

Dry mass. While plant growth was not visually impacted by $\mathrm{Si}$ supplementation,

Table 1. Solution $\mathrm{pH}$, electrical conductivity (EC), and silicon ( $\mathrm{Si}$ ) concentration of leachate samples (mean $\pm \mathrm{SE}$ ) collected following the pour-through procedure, and Si concentration in leaves, stems, flowers, and roots of eight petunia (Petunia $\times$ hybrida) cultivars grown in soilless substrate and fertilized with ( $2 \mathrm{~mm}$ ) or without (0 mM) supplemental $\mathrm{Si}$, provided as potassium silicate, at every irrigation.

\begin{tabular}{|c|c|c|c|c|c|c|c|c|}
\hline$\underline{\mathrm{Si}}$ & Cultivar $^{2}$ & $\mathrm{pH}$ & $\mathrm{EC}\left(\mathrm{mS} \cdot \mathrm{cm}^{-1}\right)$ & $\begin{array}{l}\text { Pour-through Si } \\
\left(\mathrm{mg} \cdot \mathrm{L}^{-1}\right)\end{array}$ & Leaf Si $\left(\mathrm{mg} \cdot \mathrm{kg}^{-1}\right)$ & Stem Si $\left(\mathrm{mg} \cdot \mathrm{kg}^{-1}\right)$ & Flower Si $\left(\mathrm{mg} \cdot \mathrm{kg}^{-1}\right)$ & Root Si $\left(\mathrm{mg} \cdot \mathrm{kg}^{-1}\right)$ \\
\hline \multirow[t]{6}{*}{$0 \mathrm{~mm}$} & Black Cherry & $6.02 \pm 0.06$ & $3.76 \pm 0.17$ & $2.90 \pm 0.23$ & $452 \pm 43$ & $380 \pm 76$ & $117 \pm 33$ & $354 \pm 35$ \\
\hline & Limoncello & $5.87 \pm 0.05$ & $3.30 \pm 0.21$ & $1.75 \pm 0.21$ & $1295 \pm 396$ & $155 \pm 23$ & $97 \pm 31$ & $103 \pm 14$ \\
\hline & Priscilla & $5.83 \pm 0.05$ & $3.69 \pm 0.18$ & $2.51 \pm 0.18$ & $866 \pm 116$ & $84 \pm 14$ & $169 \pm 67$ & $237 \pm 48$ \\
\hline & Royal Velvet & $5.79 \pm 0.02$ & $3.27 \pm 0.13$ & $0.98 \pm 0.13$ & $643 \pm 194$ & $173 \pm 49$ & $437 \pm 96$ & $653 \pm 169$ \\
\hline & Sangria Charm & $5.71 \pm 0.03$ & $3.72 \pm 0.19$ & $1.97 \pm 0.20$ & $349 \pm 69$ & $49 \pm 8$ & $253 \pm 81$ & $589 \pm 130$ \\
\hline & Silverberry & $5.61 \pm 0.05$ & $3.81 \pm 0.14$ & $1.70 \pm 0.14$ & $243 \pm 27$ & $99 \pm 37$ & $209 \pm 62$ & $240 \pm 52$ \\
\hline \multirow{6}{*}{$2 \mathrm{~mm}$} & Priscilla & $6.02 \pm 0.05$ & $2.10 \pm 0.14$ & $28.79 \pm 1.07$ & $2732 \pm 240$ & $361 \pm 23$ & $311 \pm 42$ & $10,457 \pm 1270$ \\
\hline & Raspberry Blast & $6.17 \pm 0.07$ & $1.50 \pm 0.08$ & $26.40 \pm 1.44$ & $1660 \pm 143$ & $195 \pm 20$ & $363 \pm 65$ & $4370 \pm 838$ \\
\hline & Royal Velvet & $5.98 \pm 0.03$ & $1.50 \pm 0.09$ & $25.68 \pm 1.20$ & $2715 \pm 329$ & $444 \pm 31$ & $891 \pm 218$ & $7439 \pm 604$ \\
\hline & Sangria Charm & $5.85 \pm 0.06$ & $1.87 \pm 0.10$ & $31.97 \pm 0.84$ & $1877 \pm 88$ & $233 \pm 37$ & $657 \pm 133$ & $9358 \pm 640$ \\
\hline & Silverberry & $5.87 \pm 0.04$ & $2.07 \pm 0.12$ & $28.77 \pm 0.77$ & $1248 \pm 64$ & $248 \pm 27$ & $463 \pm 117$ & $4362 \pm 352$ \\
\hline & White & $5.99 \pm 0.04$ & $1.66 \pm 0.06$ & $28.58 \pm 1.05$ & $1992 \pm 158$ & $289 \pm 66$ & $253 \pm 22$ & $4724 \pm 461$ \\
\hline
\end{tabular}

z‘Supertunia Black Cherry' (Black Cherry), 'Supertunia Limoncello' (Limoncello), 'Supertunia Priscilla' (Priscilla), 'Supertunia Raspberry Blast' (Raspberry Blast), 'Supertunia Royal Velvet' (Royal Velvet), 'Supertunia Sangria Charm' (Sangria Charm), 'Supertunia Vista Silverberry' (Silverberry), and 'Supertunia White Improved' (White)

${ }^{\mathrm{y}}$ Analysis of variance (significant at $P \leq 0.05$ ).

${ }^{\mathrm{x}}$ Tukey's honestly significant difference $(\alpha=0.05)$ for cultivar $\times$ Si interactions. 
Table 2. Dry mass (mean $\pm \mathrm{sE}$ ) for eight petunia (Petunia $\times$ hybrida) cultivars grown in soilless substrate and fertilized with $(2 \mathrm{~mm})$ or without $(0 \mathrm{mM})$ supplemental silicon $(\mathrm{Si})$, provided as potassium silicate, at every irrigation.

\begin{tabular}{|c|c|c|c|c|c|c|}
\hline Source & Treatment & Leaf dry mass (g) & Flower dry mass (g) & Stem dry mass (g) & Root dry mass (g) & Total dry mass $(\mathrm{g})$ \\
\hline \multirow{6}{*}{ Cultivar } & Limoncello & $4.84 \pm 0.13$ & $1.00 \pm 0.12$ & $5.45 \pm 0.18$ & $0.52 \pm 0.02$ & $11.82 \pm 0.26$ \\
\hline & Priscilla & $4.35 \pm 0.13$ & $3.59 \pm 0.20$ & $4.64 \pm 0.16$ & $0.43 \pm 0.02$ & $13.01 \pm 0.29$ \\
\hline & Raspberry Blast & $6.47 \pm 0.09$ & $1.96 \pm 0.08$ & $9.03 \pm 0.21$ & $0.62 \pm 0.03$ & $18.07 \pm 0.26$ \\
\hline & Sangria Charm & $5.68 \pm 0.16$ & $0.89 \pm 0.06$ & $7.69 \pm 0.18$ & $0.44 \pm 0.02$ & $14.70 \pm 0.33$ \\
\hline & Silverberry & $7.00 \pm 0.14$ & $0.88 \pm 0.11$ & $7.89 \pm 0.30$ & $0.42 \pm 0.02$ & $16.19 \pm 0.44$ \\
\hline & White Imp. & $5.48 \pm 0.11$ & $2.98 \pm 0.12$ & $9.56 \pm 0.16$ & $0.43 \pm 0.02$ & $18.44 \pm 0.26$ \\
\hline $\mathrm{Si}$ & HSD & 0.17 & - & - & 0.03 & - \\
\hline \multirow[t]{3}{*}{ ANOVA $^{\mathrm{x}}$} & $\mathrm{Cv}$ & $<0.0001$ & $<0.0001$ & $<0.0001$ & $<0.0001$ & $<0.0001$ \\
\hline & $\mathrm{Si}$ & 0.0089 & $<0.0001$ & 0.5958 & 0.0064 & 0.7906 \\
\hline & $\mathrm{Cv} \times \mathrm{Si}$ & 0.1474 & $<0.0001$ & 0.5828 & 0.6964 & 0.7450 \\
\hline
\end{tabular}

“'Supertunia Black Cherry' (Black Cherry), 'Supertunia Limoncello' (Limoncello), 'Supertunia Priscilla' (Priscilla), 'Supertunia Raspberry Blast' (Raspberry Blast), 'Supertunia Royal Velvet' (Royal Velvet), 'Supertunia Sangria Charm' (Sangria Charm), 'Supertunia Vista Silverberry’ (Silverberry), and 'Supertunia White Improved' (White).

${ }^{\mathrm{y}}$ Tukey's honestly significant difference $(\alpha=0.05)$; hyphen for HSD indicates value not reported due to either a nonsignificant main effect or a significant cultivar $\times$ Si interaction for the variable of interest.

${ }^{\mathrm{x}}$ Analysis of variance (significant at $P \leq 0.05$ ).

Table 3. Silicon ( $\mathrm{Si}$ ) content ( $\mathrm{mg}$ per plant) of leaves, stems, flowers, and roots (mean $\pm \mathrm{SE}$ ) of eight petunia (Petunia $\times$ hybrida) cultivars grown in soilless substrate and fertilized with $(2 \mathrm{~mm})$ or without $(0 \mathrm{~mm})$ supplemental $\mathrm{Si}$, provided as potassium silicate, at every irrigation.

\begin{tabular}{|c|c|c|c|c|c|c|}
\hline$\overline{\mathrm{Si}}$ & Cultivar $^{2}$ & Si_leaf & Si_stem & Si_flower & Si_root & Si_total \\
\hline \multirow[t]{6}{*}{$\overline{0 \mathrm{~mm}}$} & Black Cherry & $1.53 \pm 0.13$ & $1.42 \pm 0.30$ & $0.08 \pm 0.02$ & $0.17 \pm 0.02$ & $3.20 \pm 0.35$ \\
\hline & Priscilla & $3.53 \pm 0.51$ & $0.38 \pm 0.07$ & $0.70 \pm 0.27$ & $0.10 \pm 0.02$ & $4.70 \pm 0.63$ \\
\hline & Raspberry Blast & $1.71 \pm 0.18$ & $0.41 \pm 0.06$ & $0.32 \pm 0.04$ & $0.41 \pm 0.07$ & $2.85 \pm 0.26$ \\
\hline & Sangria Charm & $2.01 \pm 0.44$ & $0.39 \pm 0.06$ & $0.26 \pm 0.09$ & $0.30 \pm 0.09$ & $2.96 \pm 0.45$ \\
\hline & Silverberry & $1.66 \pm 0.18$ & $0.74 \pm 0.24$ & $0.14 \pm 0.04$ & $0.10 \pm 0.02$ & $2.63 \pm 0.35$ \\
\hline & White & $2.07 \pm 0.20$ & $0.64 \pm 0.12$ & $0.86 \pm 0.42$ & $0.07 \pm 0.01$ & $3.63 \pm 0.44$ \\
\hline \multirow{6}{*}{$2 \mathrm{~mm}$} & Priscilla & $12.75 \pm 1.08$ & $1.78 \pm 0.12$ & $0.94 \pm 0.08$ & $4.00 \pm 0.49$ & $19.46 \pm 1.25$ \\
\hline & Raspberry Blast & $10.52 \pm 0.73$ & $1.80 \pm 0.20$ & $0.70 \pm 0.17$ & $2.38 \pm 0.36$ & $15.40 \pm 0.73$ \\
\hline & Royal Velvet & $10.91 \pm 0.93$ & $2.78 \pm 0.21$ & $1.62 \pm 0.14$ & $1.73 \pm 0.16$ & $17.04 \pm 0.93$ \\
\hline & Sangria Charm & $10.82 \pm 0.62$ & $1.84 \pm 0.34$ & $0.52 \pm 0.36$ & $3.87 \pm 0.36$ & $17.05 \pm 1.10$ \\
\hline & Silverberry & $8.85 \pm 0.49$ & $1.91 \pm 0.21$ & $0.49 \pm 0.11$ & $1.87 \pm 0.16$ & $13.11 \pm 0.75$ \\
\hline & White & $10.93 \pm 0.71$ & $2.65 \pm 0.52$ & $0.75 \pm 0.20$ & $1.96 \pm 0.25$ & $16.30 \pm 1.22$ \\
\hline ANOVA $^{y}$ & $\mathrm{Cv}$ & $<0.0001$ & $<0.0001$ & $<0.0001$ & $<0.0001$ & $<0.0001$ \\
\hline
\end{tabular}

z‘Supertunia Black Cherry' (Black Cherry), 'Supertunia Limoncello' (Limoncello), 'Supertunia Priscilla' (Priscilla), 'Supertunia Raspberry Blast' (Raspberry Blast), 'Supertunia Royal Velvet' (Royal Velvet), 'Supertunia Sangria Charm' (Sangria Charm), 'Supertunia Vista Silverberry' (Silverberry), and 'Supertunia White Improved' (White).

${ }^{\mathrm{y}}$ Analysis of variance (significant at $P \leq 0.05$ ).

${ }^{\mathrm{x}}$ Tukey's honestly significant difference $(\alpha=0.05)$; hyphen for HSD indicates value not reported, based on which ANOVA effects were significant for the variable of interest.

some small differences did occur (Table 2). Leaf dry mass increased $4.5 \%$ with supplemental $\mathrm{Si}(5.10 \pm 0.14$ vs. $5.33 \pm 0.13 \mathrm{~g}$ for 0 and $2 \mathrm{mM} \mathrm{Si}$, respectively, pooled across cultivars; $P=0.0089)$. Stem dry mass was unaffected by $\mathrm{Si}(P>0.05)$. Flower dry mass was affected by the interaction of cultivar and Si $(P<0.0001)$, and it ranged between $0.55 \pm$ $0.08 \mathrm{~g}$ (Black Cherry, $2 \mathrm{~mm} \mathrm{Si}$ ) and $4.25 \pm$ $0.16 \mathrm{~g}$ (Priscilla, $0 \mathrm{~mm}$ ). Six cultivars exhibited no difference in flower dry mass when supplied 0 or $2 \mathrm{~mm} \mathrm{Si}$; but two cultivars, Priscilla and Royal Velvet, had a $31 \%$ lower flower dry mass when supplied $2 \mathrm{~mm}$ Si. Root dry mass decreased $9.5 \%$ with supplemental Si $(0.46 \pm 0.02$ vs. $0.42 \pm 0.01 \mathrm{~g}$, respectively, pooled across cultivars; $P=$ 0.0064).

Si content. Silicon content (calculated from Si concentration and tissue dry mass) was affected by the main effects of cultivar and $\mathrm{Si}$ in the leaves, stems, and flowers $(P<$ 0.0001 for all; Table 3). Leaves, stems, and flowers averaged $2.68 \pm 0.32,0.73 \pm 0.07$, and $0.46 \pm 0.09 \mathrm{mg}$ Si per plant, respectively, for plants grown without supplemental $\mathrm{Si}$; and $11.30 \pm 0.42,2.28 \pm 0.12$, and $0.78 \pm$ $0.08 \mathrm{mg}$ Si per plant, respectively, in plants grown with supplemental Si. Root Si content $(P<0.0001$ for cultivar $\times \mathrm{Si}$ interaction $)$ ranged between $0.06 \pm 0.01 \mathrm{mg}$ Si per plant (Limoncello, $0 \mathrm{~mm} \mathrm{Si}$ ) and $4.83 \pm 0.43 \mathrm{mg}$
Si per plant (Limoncello, $2 \mathrm{~mm} \mathrm{Si}$; Table 2). Total Si content $(P=0.0004$ for cultivar $\times \mathrm{Si}$ interaction) ranged from $2.63 \pm 0.35 \mathrm{mg} \mathrm{Si}$ per plant (Silverberry, $0 \mathrm{~mm} \mathrm{Si}$ ) to $26.14 \pm$ $1.86 \mathrm{mg}$ Si per plant (Limoncello, $2 \mathrm{~mm} \mathrm{Si}$; Table 3). Supplemental Si increased root and total plant Si content in all eight cultivars, and the interactions resulted from differences in the magnitude of increase in individual cultivars in response to supplemental Si.

Si distribution. The percent of total plant Si localized in leaves ranged between $51.2 \% \pm$ $5.1 \%$ and $76.8 \% \pm 6.5 \%$ in the $0 \mathrm{~mm} \mathrm{Si}$ treatment, and between $63.5 \% \pm 2.7 \%$ and $67.7 \% \pm 1.2 \%$ in the $2 \mathrm{~mm} \mathrm{Si}$ treatment 
Table 4. Silicon ( $\mathrm{Si}$ ) distribution (mean $\pm \mathrm{SE}$ ) in eight petunia (Petunia $\times$ hybrida) cultivars grown in soilless substrate and fertilized with $(2 \mathrm{mM})$ or without $(0 \mathrm{~mm})$ supplemental Si, provided as potassium silicate, at every irrigation.

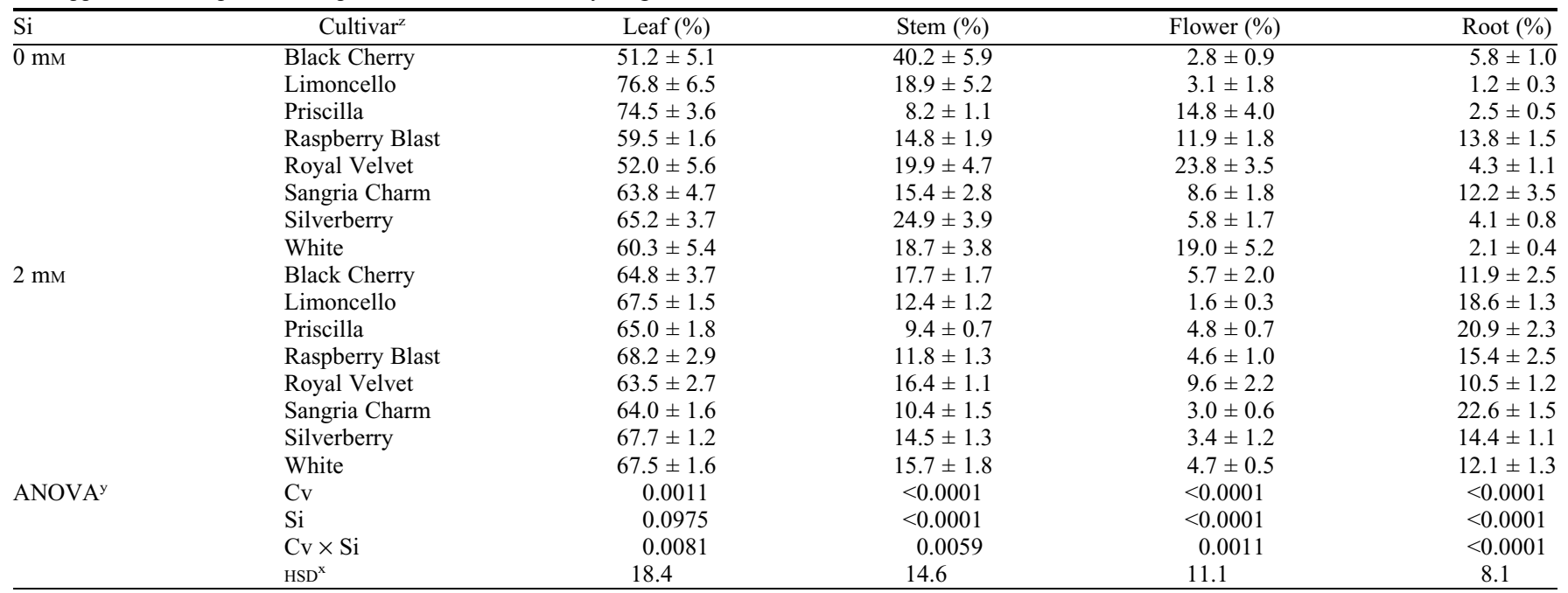

z'Supertunia Black Cherry' (Black Cherry), 'Supertunia Limoncello' (Limoncello), 'Supertunia Priscilla' (Priscilla), 'Supertunia Raspberry Blast' (Raspberry Blast), 'Supertunia Royal Velvet' (Royal Velvet), 'Supertunia Sangria Charm' (Sangria Charm), 'Supertunia Vista Silverberry' (Silverberry), and 'Supertunia White Improved' (White).

${ }^{\mathrm{y}}$ Analysis of variance (significant at $P \leq 0.05$ ).

${ }^{x}$ Tukey's honestly significant difference $(\alpha=0.05)$ for cultivar $\times$ Si interactions.

Table 5. Percent of applied silicon ( $\mathrm{Si}$ ) taken up by eight petunia (Petunia $\times$ hybrida) cultivars grown in soilless substrate and fertilized with $2 \mathrm{~mm}$ supplemental $\mathrm{Si}$, provided as potassium silicate, at every irrigation (mean $\pm \mathrm{SE}$ ). Control plants that received no supplemental Si were maintained, to account for background Si levels in substrates, other applied fertilizers, or irrigation water.

\begin{tabular}{lccc}
\hline Cultivar & $\begin{array}{c}\text { Cumulative volume } \\
\text { of nutrient solution } \\
\text { applied }(\mathrm{mL})\end{array}$ & $\begin{array}{c}\text { Percent incorporation } \\
\text { (based on total Si applied } \\
\text { during fertigation) }\end{array}$ & $\begin{array}{c}\text { Percent incorporation } \\
\text { (after subtracting Si uptake } \\
\text { by 0 mM trt) }\end{array}$ \\
\hline Limoncello & 3500 & $11.97 \%$ & $8.75 \%$ \\
Raspberry Blast & 4400 & $8.59 \%$ & $7.20 \%$ \\
Priscilla & 3900 & $9.39 \%$ & $7.05 \%$ \\
Sangria Charm & 3700 & $6.62 \%$ & $5.49 \%$ \\
White & 4400 & $6.62 \%$ & $5.37 \%$ \\
Royal Velvet & 4600 & $6.84 \%$ & $5.09 \%$ \\
Black Cherry & 3200 & $6.49 \%$ & $4.75 \%$ \\
Silverberry & 4450 & $5.32 \%$ & $4.18 \%$ \\
\hline
\end{tabular}

z'Supertunia Black Cherry' (Black Cherry), 'Supertunia Limoncello' (Limoncello), 'Supertunia Priscilla' (Priscilla), 'Supertunia Raspberry Blast' (Raspberry Blast), 'Supertunia Royal Velvet' (Royal Velvet), 'Supertunia Sangria Charm' (Sangria Charm), 'Supertunia Vista Silverberry' (Silverberry), and 'Supertunia White Improved' (White).

(Table 4). The cultivar $\times$ Si interaction $(P=$ $0.0081)$ occurred due to variation in leaf allocation across cultivars in the $0 \mathrm{~mm} \mathrm{Si}$ treatment. Leaf $\mathrm{Si}$ allocation was similar between Si treatments for all cultivars. Percent of total plant $\mathrm{Si}$ localized in stems ranged between $8.2 \% \pm 1.1 \%$ and $40.2 \% \pm$ $5.9 \%$ in the $0 \mathrm{~mm}$ Si treatment, and between $9.4 \% \pm 0.7 \%$ and $17.7 \% \pm 1.7 \%$ in the $2 \mathrm{~mm}$ Si treatment $(P=0.0059$ for cultivar $\times \mathrm{Si}$ interaction; Table 4). Only Black Cherry differed between Si treatments, and it had a greater percent $\mathrm{Si}$ accumulation in stems when supplied $0 \mathrm{~mm}$ Si compared with $2 \mathrm{~mm}$ Si. Percent of total plant Si localized in flowers ranged between $2.8 \% \pm 0.9 \%$ and $23.8 \% \pm 3.5 \%$ with $0 \mathrm{~mm} \mathrm{Si}$, and between $1.6 \% \pm 0.3 \%$ and $9.6 \% \pm 2.2 \%$ with $2 \mathrm{~mm} \mathrm{Si}$ $(P=0.0011$ for cultivar $\times \mathrm{Si}$ interaction; Table 4). Royal Velvet and White differed between Si treatments, and both had higher percent accumulation of $\mathrm{Si}$ in flowers at $0 \mathrm{~mm}$ Si compared with $2 \mathrm{~mm}$ Si. Percent of total plant $\mathrm{Si}$ localized in roots ranged between $1.2 \% \pm 0.3 \%$ and $13.8 \% \pm 1.5 \%$ in the $0 \mathrm{~mm} \mathrm{Si}$ treatment, and between $10.5 \% \pm 1.2 \%$ and $22.6 \% \pm 1.5 \%$ in the $2 \mathrm{~mm}$ Si treatment $(P<0.0001$ for cultivar $\times$ Si interaction; Table 4). Root allocation was higher in the $2 \mathrm{~mm}$ Si treatment, compared with the $0 \mathrm{~mm}$ Si treatment, in five of the eight cultivars evaluated (Limoncello, Priscilla, Sangria Charm, Silverberry, and White).

Percent of applied Si incorporated into plants. Knowing the volume of nutrient solution applied to each cultivar, the $\mathrm{Si}$ concentration $\left(2 \mathrm{mM} \mathrm{Si}=56 \mathrm{mg} \cdot \mathrm{L}^{-1}\right)$, and plant $\mathrm{Si}$ content, we calculated the percent of applied $\mathrm{Si}$ from potassium silicate incorporated by each cultivar. It ranged from $4.18 \%$ to $8.75 \%$ (Table 5).

\section{Discussion}

In the eight genotypes evaluated, maximum $\mathrm{Si}$ concentrations attained without supplemental Si were $380 \mathrm{mg} \cdot \mathrm{kg}^{-1}$ in stems, 437 $\mathrm{mg} \cdot \mathrm{kg}^{-1}$ in flowers, $653 \mathrm{mg} \cdot \mathrm{kg}^{-1}$ in roots, and $1295 \mathrm{mg} \cdot \mathrm{kg}^{-1}$ in leaves. Leaf Si concentrations ranged from 243 to $1295 \mathrm{mg} \cdot \mathrm{kg}^{-1}$, with five of eight cultivars accumulating less than $500 \mathrm{mg} \cdot \mathrm{kg}^{-1}$ (Table 1 ). These values are similar to leaf $\mathrm{Si}$ concentrations previously reported for petunia grown in soilless substrate without Si supplementation. Mattson and Leatherwood (2010) observed 211 $\mathrm{mg} \cdot \mathrm{kg}^{-1} \mathrm{Si}$ in leaves of 'Cascadias Cherry Spark', and we have observed between 263 and $946 \mathrm{mg} \cdot \mathrm{kg}^{-1}$ in 'Dreams Pink' in our own studies (Boldt et al., 2018; J. Boldt, unpublished data). However, petunia 'White Madness' grown hydroponically in ultra-purified water had nondetectable foliar concentrations of Si (Frantz et al., 2008). This suggests cultivar selection, growing conditions, and the presence of background Si (e.g., in soilless substrate components, irrigation water, and fertilizers) can affect foliar Si even when supplemental Si is not supplied. Although we minimized background $\mathrm{Si}$ from the irrigation water (below detectable limit, or $<0.01 \mathrm{mg} \cdot \mathrm{L}^{-1}$ ) in our study, the substrate components did supply some $\mathrm{Si}$; nonsupplemented plants had accumulated up to $7.25 \mathrm{mg} \mathrm{Si}$ by the end of the experiment. Sphagnum peatmoss has been shown to release small amounts of $\mathrm{Si}$ into the substrate solution $(<1 \mathrm{mg}$ Si per L of water per $\mathrm{g}$ of sphagnum peatmoss; Frantz et al. 2010). While our substrate did also contain perlite, a potassium sodium aluminum silicate that contains $73 \% \mathrm{SiO}_{2}(34 \% \mathrm{Si})$, it is chemically inert and not readily available for plant uptake (Olympios, 1992).

Silicon concentration increased, as expected, in response to $\mathrm{Si}$ supplementation, 
often in a cultivar-specific response. Maximum Si concentrations attained in our study with $2 \mathrm{~mm}$ supplemental Si were $654 \mathrm{mg} \cdot \mathrm{kg}^{-1}$ in stems, $1383 \mathrm{mg} \cdot \mathrm{kg}^{-1}$ in flowers, 3541 $\mathrm{mg} \cdot \mathrm{kg}^{-1}$ in leaves, and $10,457 \mathrm{mg} \cdot \mathrm{kg}^{-1}$ in roots (Table 1). Foliar $\mathrm{Si}$ concentrations ranged from 1248 to $3541 \mathrm{mg} \cdot \mathrm{kg}^{-1}$, which overlaps with concentrations observed previously for petunia 'Dreams Pink' grown in a rice hull-amended soilless substrate (2036 $\mathrm{mg} \cdot \mathrm{kg}^{-1}$; Boldt et al., 2018) or grown in a soilless substrate and fertilized with $2 \mathrm{~mm} \mathrm{Si}$ (894 to $1576 \mathrm{mg} \cdot \mathrm{kg}^{-1}$, J. Boldt, unpublished data). However, the foliar Si concentrations in our current and prior studies were higher than the $506 \mathrm{mg} \cdot \mathrm{kg}^{-1}$ observed in petunia 'Cascadias Cherry Spark' drenched weekly with $250 \mathrm{~mL}$ of a $100 \mathrm{mg} \cdot \mathrm{L}^{-1}$ potassium silicate solution (Mattson and Leatherwood, 2010) or the $197 \mathrm{mg} \cdot \mathrm{kg}^{-1} \mathrm{Si}$ observed in petunia 'White Madness' grown hydroponically with $2 \mathrm{~mm}$ potassium silicate (Frantz et al., 2008). As mentioned previously, these differences may be due to the growing system (soilless substrate vs. hydroponics), Si application method, environmental growth conditions, or cultivar. Other floricultural crops, including low and high Si accumulators, have also exhibited an increase in foliar $\mathrm{Si}$ in response to potassium silicate supplementation (hydroponic or drench application), including snapdragon 'Bedding Rocket White' (Frantz et al., 2011), rose (Rosa hybrida 'Meipelta') (Gillman et al., 2003), chrysanthemum (Dendranthema grandiflorum 'Shinro') (Jeong et al., 2012), gerbera (Gerbera hybrid L. 'Acapella') (Kamenidou et al., 2010), sunflower 'Ring of Fire' (Kamenidou et al., 2008, 2011), and zinnia 'Oklahoma Formula Mix' (Kamenidou et al., 2009).

Highest $\mathrm{Si}$ concentrations in Sisupplemented plants were localized in roots, followed by leaves, and then lower (but similar) values in flowers and stems (analysis not shown). Few studies have directly compared root and shoot $\mathrm{Si}$ concentrations. In low-Si accumulator species, higher root $\mathrm{Si}$ concentrations compared with foliar Si concentrations have been observed in tomato (Solanum lycopersicum Mill.) grown in 0 and $1 \mathrm{~mm}$ Si-amended nutrient solutions (Heine et al., 2005), in petunia 'Dreams Pink' grown in a rice hull-amended soilless substrate (Boldt et al., 2018), and in the eight cultivars evaluated in this study. However, in intermediate and high-Si accumulator species, higher shoot Si concentrations compared with root Si concentrations have been observed in bitter gourd (Mormodica charantia) grown in 0 and $1 \mathrm{~mm}$ Si-amended nutrient solutions (Heine et al., 2005), in sunflower 'Pacino Gold' grown in a rice hull-amended soilless substrate (Boldt et al., 2018), and in rice grown in $0.5,1$, and $2 \mathrm{~mm}$ Si-amended nutrient solutions (Guo et al., 2005).

The trend of detecting higher root $\mathrm{Si}$ concentrations (compared with foliar) in low Si accumulators, and lower root Si concentrations (compared with foliar) in $\mathrm{Si}$ accumulators following $\mathrm{Si}$ supplementation raises a few points for discussion.
First, this trend extends to the magnitude of increase in Si following supplementation. In our study, the largest percent increase in $\mathrm{Si}$ was localized in the roots. For comparison, $\mathrm{Si}$ concentration increased $173 \%$ to $534 \%$ in the leaves and $593 \%$ to $9161 \%$ in the roots. Similarly, other studies have reported increased shoot $\mathrm{Si}$, but to a lesser extent, relative to root $\mathrm{Si}$ in petunia 'Dreams Pink' (115\% vs. $688 \%$, respectively) and tomato ( $117 \%$ vs. $173 \%$, respectively), both low $\mathrm{Si}$ accumulators (Boldt et al., 2018; Heine et al., 2005). In contrast, shoot Si increased more than root $\mathrm{Si}$ in bitter gourd ( $402 \%$ vs. $247 \%$, respectively; intermediate $\mathrm{Si}$ accumulator) and sunflower (766\% vs. 414\%, respectively; high $\mathrm{Si}$ accumulator) (Boldt et al., 2018; Heine et al., 2005). Plants have traditionally been classified as low, intermediate, or high $\mathrm{Si}$ accumulators based on foliar concentrations. Less attention has been given to root $\mathrm{Si}$ concentrations, the relative balance between root and shoot Si concentrations across crops, and the relative percent increase in $\mathrm{Si}$ when provided supplemental $\mathrm{Si}$; but these factors should not be overlooked.

Second, Si translocation from roots to shoots is regulated by efflux transporters. Variation in transporter activity and density between low and high accumulators may explain why low Si accumulators have higher root $\mathrm{Si}$ concentrations than $\mathrm{Si}$ accumulators, under supplemented and nonsupplemented conditions, and why they have a greater percent accumulation following supplementation. One hypothesis is that $\mathrm{Si}$ efflux may be more tightly controlled in low $\mathrm{Si}$ accumulator species and less tightly controlled in $\mathrm{Si}$ accumulator species. Presently, however, regulation of Si translocation from roots to aerial portions of the plant is not well characterized in low $\mathrm{Si}$ accumulators. Another contributing factor may be transporter density, with fewer transporters correlating to a shift toward higher root (rather than shoot) Si accumulation. Mitani and Ma (2005) observed a decrease in Si transporter density in the plasma membrane of rice, cucumber, and tomato, respectively, which corresponded to foliar $\mathrm{Si}$ concentrations.

Last, numerous studies have reported the effectiveness of $\mathrm{Si}$ in mitigating foliar fungal pathogens, namely powdery mildews (e.g., Blumeria graminis f. sp. tritici, Erysiphe cichoracearum, and Sphaerotheca fulginea), leaf blast (e.g., Magnaporthe grisea in rice), and rust (Puccinia sp.), in Si accumulators (Bakhat et al., 2018; Chain et al., 2009; Datnoff et al., 1997; Fauteux et al., 2006; Guével et al., 2007; Menzies et al., 1992). Although many greenhouse-grown crops are low foliar Si accumulators, it is possible they, like petunia in this study, accumulate appreciable root $\mathrm{Si}$ following supplementation. This may, in turn, provide benefit against commonly encountered root pathogens in ornamental crop production (e.g., Pythium, Phytophthora, Rhizoctonia, and Thielaviopsis), and consideration should be given to investigating its effectiveness. For example, $\mathrm{Si}$ supplementation reduced fusarium wilt
(Fusarium oxysporum f. sp. cubense) in banana (Musa acuminata) (Fortunato et al., 2012) and $P$. ultimum in cucumber (Bélanger et al., 1995), but it had limited effectiveness against $P$. aphanidermatum in bitter gourd (Heine et al., 2007).

The substantial increase in root Si content of plants grown with $2 \mathrm{~mm} \mathrm{Si}$ altered the distribution of Si between nonsupplemented and supplemented plants. For example, the allocation of $\mathrm{Si}$ to flowers decreased from $19.0 \%$ to $4.7 \%$ in White, respectively, with a corresponding increase to roots, from $2.1 \%$ to $12.1 \%$ (Table 4). Percent of total plant Si stored in roots increased in five of the eight cultivars, while leaf Si allocation remained unchanged in all cultivars. The increased deposition of $\mathrm{Si}$ in $\mathrm{Si}$-supplemented petunia roots $(10.5 \%$ to $22.6 \%)$ was much greater than what has been seen in $\mathrm{Si}$ accumulators, where root $\mathrm{Si}$ was about $2 \%$ of total plant $\mathrm{Si}$ accumulation in oat (Jones and Handreck, 1967).

Assuming Si released from the soilless substrate was similar in both the 0 and $2 \mathrm{~mm}$ $\mathrm{Si}$ treatments, the percent of $\mathrm{Si}$ applied as liquid potassium silicate that was taken up and incorporated ranged from $4.18 \%$ in Silverberry to $8.75 \%$ in Limoncello (Table 5). These were relatively low values, considering the cost of applying potassium silicate. To increase uptake efficiency, a lower concentration could be supplied to low $\mathrm{Si}$ accumulators, or Si supplementation could be provided at regular intervals but not at every irrigation.

Plant growth was not visually impacted by $\mathrm{Si}$ supplementation, although leaf dry mass increased $4.5 \%$, flower dry mass decreased $31 \%$ in two cultivars (Priscilla and Royal Velvet), and root dry mass decreased $9.5 \%$ (Table 2 ). While not a primary objective of this study, we did also analyze foliar macro- and micronutrient concentrations. Leaf nutrient status varied in response to $\mathrm{Si}$ supplementation (Supplemental Table 1), but not substantially enough to impact growth and development. Although statistically significant differences between $\mathrm{Si}$ treatments were observed for many foliar macro- and micronutrients (all except copper and zinc), values remained within recommended tissue nutrient ranges. Silicon supplementation also influenced leachate $\mathrm{pH}$ and EC. Except for Black Cherry, leachate $\mathrm{pH}$ was $\approx 0.2$ units greater and $\mathrm{EC}$ was 1.3 to $1.8 \mathrm{mS} \cdot \mathrm{cm}^{-1}$ lower in Si-supplemented plants, despite adjusting starting $\mathrm{pH}$ and $\mathrm{EC}$ to similar values in both nutrient solutions. Across cultivars, EC was inversely related to dry mass $(r=-0.52$ and -0.73 in the 0 and $2 \mathrm{~mm} \mathrm{Si}$ treatments, respectively).

The eight cultivars in this study, while from one distributor, originated from five different breeding programs (J. Tatro, personal communication). This genetic diversity, and the corresponding variability in $\mathrm{Si}$ concentrations observed, suggests there is potential to select plants with enhanced $\mathrm{Si}$ uptake or preferred Si distribution. However, it should first be established that enhanced $\mathrm{Si}$ 
uptake in petunia will correspond with abiotic or biotic stress tolerance. While the addition of $\mathrm{Si}$ did not substantially impact plant growth in this study, previous studies have shown that growth differences and benefits of $\mathrm{Si}$ supplementation are generally more pronounced when plants are grown in the presence of biotic or abiotic stresses (Chérif et al., 1994; Epstein, 1999; Flora et al., 2019; Frantz et al., 2011).

In summary, a key finding of this study was the appreciable accumulation of $\mathrm{Si}$ in roots of a low $\mathrm{Si}$ accumulator following $\mathrm{Si}$ supplementation, both in terms of Si concentration and the magnitude of increase observed. Leaves contained the highest concentrations of $\mathrm{Si}$ in nonsupplemented plants, but this shifted to roots in Sisupplemented plants. This trend was consistent across all eight cultivars evaluated.

\section{Literature Cited}

Agarie, S., N. Hanaoka, O. Ueno, A. Miyazaki, F. Kubota, W. Agata, and P.B. Kaufman. 1998. Effects of silicon on tolerance to water deficit and heat stress in rice plants (Oryza sativa L.), monitored by electrolyte leakage. Plant Prod. Sci. 1:96-103, doi: 10.1626/pps.1.96.

Bakhat, H.F., N. Bibi, Z. Zia, S. Abbas, H.M. Hammad, S. Fahad, M.R. Ashraf, G.M. Shah, F. Rabbani, and S. Saeed. 2018. Silicon mitigates biotic stresses in crop plants: A review. Crop Prot. 104:21-34, doi: 10.1016/j.cropro.2017.10.008.

Bélanger, R.R., P.A. Bowen, D.L. Ehret, and J.G. Menzies. 1995. Soluble silicon: Its role in crop and disease management of greenhouse crops. Plant Dis. 79:329-336.

Boldt, J.K., J.C. Locke, and J.E. Altland. 2018. Silicon accumulation and distribution in petunia and sunflower grown in a rice hull-amended substrate. HortScience 53:698-703, doi: 10.21273/ HORTSCI12325-17.

Chain, F., C. Côté-Beaulieu, F. Belzile, J.G. Menzies, and R.R. Bélanger. 2009. A comprehensive transcriptomic analysis of the effect of silicon on wheat plants under control and pathogen stress conditions. Mol. Plant Microbe Interact. 22:1323-1330, doi: 10.1094/MPMI22-11-1323.

Chérif, M., J.G. Menzies, D.L. Ehret, C. Bogdanoff, and R.R. Bélanger. 1994. Yield of cucumber infected with Pythium aphanidermatum when grown with soluble silicon. HortScience 29:896-897, doi: 10.21273/HORTSCI.29.8.896.

Collin, B., E. Doelsch, C. Keller, F. Panfili, and J.-D. Meunier. 2012. Distribution and variability of silicon, copper and zinc in different bamboo species. Plant Soil 351:377-387, doi: 10.1007/s11104-011-0974-9.

Datnoff, L.E., C.W. Deren, and G.H. Snyder. 1997. Silicon fertilization for disease management of rice in Florida. Crop Prot. 16:525-531, doi: 10.1016/S0261-2194(97)00033-1.

Deren, C.W., B. Glaz, and G.N. Snyder. 1993. Leaf-tissue silicon content of sugarcane genotypes grown on everglades histosols. J. Plant Nutr. 16:2273-2280, doi: 10.1080/ 01904169309364685.

Deren, C.W., L.E. Datnoff, and G.N. Snyder. 1992. Variable silicon content of rice cultivars grown on everglades histosols. J. Plant Nutr. 15:23632368, doi: 10.1080/01904169209364480.

Epstein, E. 1999. Silicon. Annu. Rev. Plant Physiol. Plant Mol. Biol. 50:641-664, doi: 10.1146/ annurev.arplant.50.1.641.
Fauteux, F., F. Chain, F. Belzile, J.G. Menzies, and R.R. Bélanger. 2006. The protective role of silicon in the Arabidopsis-powdery mildew pathosystem. Proc. Natl. Acad. Sci. USA 103:17554-17559, doi: 10.1073/pnas.0606330103.

Flora, C., S. Khandekar, J. Boldt, and S. Leisner. 2019. Silicon alleviates long-term copper toxicity and influences gene expression in Nicotiana tabacum. J. Plant Nutr. 42:864-878, doi: 10.1080/01904167.2019.1589508.

Fortunato, A.A., F.A. Rodrigues, and K.J. Teles do Nascimento. 2012. Physiological and biochemical aspects of the resistance of banana plants to fusarium wilt potentiated by silicon. Phytopathology 102:957-966, doi: 10.1094/PHYTO02-12-0037-R.

Frantz, J., J.C. Locke, D.S. Sturtz, and S. Leisner. 2010. Silicon in ornamental crops: Detection, delivery, and function, p. 111-134. In: F. Rodriguez (ed.). Silicio na Agricultura: Anais do V Simposio Brasileiro sobre Silicio Agricultura. Universidade Federal de Viçosa, Viçosa, Brazil.

Frantz, J.M., J.C. Locke, L. Datnoff, M. Omer, A. Widrig, D. Sturtz, L. Horst, and C.R. Krause. 2008. Detection, distribution, and quantification of silicon in floricultural crops utilizing three distinct analytical methods. Commun. Soil Sci. Plant Anal. 39:2734-2751, doi: 10.1080/00103620802358912.

Frantz, J.M., S. Khandekar, and S. Leisner. 2011. Silicon differentially influences copper toxicity response in silicon-accumulator and nonaccumulator species. J. Amer. Soc. Hort. Sci. 136:329-338, doi: 10.21273/JASHS.136.5.329.

Gillman, J.H., D.C. Zlesak, and J.A. Smith. 2003. Applications of potassium silicate decrease black spot infection in Rosa hybrida 'Meipelta' (Fuschia Meidland $^{\mathrm{TM}}$ ). HortScience 38:11441147, doi: 10.21273/HORTSCI.38.6.1144.

Guével, M.-H., J.G. Menzies, and R.R. Bélanger. 2007. Effect of root and foliar applications of soluble silicon on powdery mildew control and growth of wheat plants. Eur. J. Plant Pathol. 119:429-436, doi: 10.1007/s10658-007-9181-1.

Guo, W., Y.-L. Hou, S.-G. Wang, and Y.-G. Zhu. 2005. Effect of silicate on the growth and arsenate uptake by rice (Oryza sativa L.) seedlings in solution culture. Plant Soil 272:173-181, doi: 10.1007/s11104-004-4732-0.

Handreck, K.A. and L.H.P. Jones. 1968. Studies of silica in the oat plant. IV, Silica content of plant parts in relation to stage of growth, supply of silica, and transpiration. Plant Soil 29:449-459, doi: 10.1007/BF01348976.

Hattori, T., S. Inanaga, H. Araki, P. An, S. Morita, M. Luxová, and A. Lux. 2005. Application of silicon enhanced drought tolerance in Sorghum bicolor. Physiol. Plant. 123:459-466, doi: 10.1111/j.1399-3054.2005.00481.x.

He, Y., H. Xiao, H. Wang, Y. Chen, and M. Yu. 2010. Effect of silicon on chilling-induced changes of solutes, antioxidants, and membrane stability in seashore paspalum turfgrass. Acta Physiol. Plant. 32:487-494, doi: 10.1007/ s11738-009-0425-x.

Heine, G., G. Tikum, and W.J. Horst. 2005. Silicon nutrition of tomato and bitter gourd with special emphasis on silicon distribution in root fractions. J. Plant Nutr. Soil Sci. 168:600-606, doi: $10.1002 /$ jpln.200420508.

Heine, G., G. Tikum, and W.J. Horst. 2007. The effect of silicon on the infection by and spread of Pythium aphanidermatum in single roots of tomato and bitter gourd. J. Expt. Bot. 58:569577, doi: $10.1093 / \mathrm{jxb} / \mathrm{erl} 232$.

Hodson, M.J., P.J. White, A. Mead, and M.R. Broadley. 2005. Phylogenetic variation in the silicon composition of plants. Ann. Bot. 96:1027-1046, doi: 10.1093/aob/mci255.

Jeong, K.J., Y.S. Chon, S.H. Ha, H.K. Kang, and J.G. Yun. 2012. Silicon application on standard chrysanthemum alleviates damage induced by disease and aphid insect. Korean J. Hort. Sci. Biotechnol. 30:21-26, doi: 10.7235/ hort.2012.11090.

Jones, L.H.P. and K.A. Handreck. 1967. Silica in soils, plants, and animals. Adv. Agron. 19:107149, doi: 10.1016/S0065-2113(08)60734-8.

Kamenidou, S., T.J. Cavins, and S. Marek. 2008. Silicon supplements affect horticultural traits of greenhouse-produced ornamental sunflowers. HortScience 43:236-239, doi: 10.21273/HORTSCI.43.1.236.

Kamenidou, S., T.J. Cavins, and S. Marek. 2009. Evaluation of silicon as a nutritional supplement for greenhouse zinnia production. Scientia Hort. 119:297-301, doi: 10.1016/j.scienta.2008.08.012.

Kamenidou, S., T.J. Cavins, and S. Marek. 2010. Silicon supplements affect floricultural quality traits and elemental nutrient concentrations of greenhouse produced gerbera. Scientia Hort. 123:390-394, doi: 10.1016/j.scienta.2009.09.008.

Kamenidou, S., T.J. Cavins, and S. Marek. 2011. Correlation between tissue and substrate silicon concentration of greenhouse produced ornamental sunflowers. J. Plant Nutr. 34:217-223, doi: 10.1080/01904167.2011.533323.

Lanning, F.C., T.L. Hopkins, and J.C. Loera. 1980. Silica and ash content and depositional patterns in tissues of mature Zea mays L. plants. Ann. Bot. 45:549-554, doi: 10.1093/oxfordjournals. aob.a085859.

LeBude, A.V. and T.E. Bilderback. 2009. The pour-through extraction procedure: A nutrient management tool for nursery crops. North Carolina State Univ. Ext. AG-717-W.

Li, J., S.M. Leisner, and J. Frantz. 2008. Alleviation of copper toxicity in Arabidopsis thaliana by silicon addition to hydroponic solutions. J. Amer. Soc. Hort. Sci. 133:670-677, doi: 10.21273/JASHS.133.5.670.

Liang, Y., J. Zhu, Z. Li, G. Chu, Y. Ding, J. Zhang, and W. Sun. 2008. Role of silicon in enhancing resistance to freezing stress in two contrasting winter wheat cultivars. Environ. Exp. Bot. 64:286-294, doi: 10.1016/j.envexpbot.2008.06.005.

Liang, Y., Q. Shen, Z. Shen, and T. Ma. 1996. Effects of silicon on salinity tolerance of two barley cultivars. J. Plant Nutr. 19:173-183, doi: 10.1080/01904169609365115

Ma, J.F. 2004. Role of silicon in enhancing the resistance of plants to biotic and abiotic stresses. Soil Sci. Plant Nutr. 50:11-18, doi: 10.1080/00380768.2004.10408447.

Ma, J.F., A. Higashitani, K. Sato, and K. Takeda. 2003. Genotypic variation in silicon concentration of barley grain. Plant Soil 249:383-387, doi: 10.1023/A:1022842421926.

Ma, J.F. and N. Yamaji. 2006. Silicon uptake and accumulation in higher plants. Trends Plant Sci. 11:392-397, doi: 10.1016/j.tplants.2006.06.007.

Ma, J.F., N. Yamaji, K. Tamai, and N. Mitani. 2007. Genotypic difference in silicon uptake and expression of silicon transporter genes in rice. Plant Physiol. 145:919-924, doi: 10.1104/ pp.107.107599.

Ma, J.F., Y. Miyake, and E. Takahashi. 2001. Silicon as a beneficial element for crop plants. Studies Plant Sci. 8:17-39, doi: 10.1016/S0928-3420(01) 80006-9.

Massey, F.P., A.R. Ennos, and S.E. Hartley. 2006. Silica in grasses as a defence against insect herbivores: Contrasting effects on folivores and a phloem feeder. J. Anim. Ecol. 75:595-603, doi: 10.1111/j.1365-2656.2006.01082.x. 
Mattson, N.S. and W.R. Leatherwood. 2010. Potassium silicate drenches increase leaf silicon content and affect morphological traits of several floriculture crops grown in a peatbased substrate. HortScience 45:43-47, doi: 10.21273/HORTSCI.45.1.43.

Menzies, J., P. Bowen, D. Ehret, and A.D.M. Glass. 1992. Foliar applications of potassium silicate reduce severity of powdery mildew on cucumber, muskmelon, and zucchini squash. J. Amer. Soc. Hort. Sci. 117:902-905, doi: 10.21273/ JASHS.117.6.902.

Mitani, N. and J.F. Ma. 2005. Uptake system of silicon in different plant species. J. Expt. Bot. 56:1255-1261, doi: 10.1093/jxb/eri121.

Murozuka, E., T.C. de Bang, J. Frydenvang, J. Lindedam, K.H. Laursen, S. Bruun, J. Magid, and J.K. Schjoerring. 2015. Concentration of mineral elements in wheat (Triticum aestivum L.) straw: Genotypic differences and consequences for enzymatic saccharification. Biomass Bioenergy 75:134-141, doi: 10.1016/ j.biombioe.2015.02.017.

Olympios, C.M. 1992. Soilless media under protected cultivation rockwool, peat, perlite and other substrates. Acta Hort. 323:215-234, doi: 10.17660/ActaHortic.1993.323.20.

Reynolds, O.L., M.G. Keeping, and J.H. Meyer. 2009. Silicon-augmented resistance of plants to herbivorous insects: A review. Ann. Appl. Biol. 155:171186, doi: 10.1111/j.1744-7348.2009.00348.x.

Romero-Aranda, M.R., O. Jurado, and J. Cuartero. 2006. Silicon alleviates the deleterious salt effect on tomato plant growth by improving plant water status. J. Plant Physiol. 163:847855, doi: 10.1016/j.jplph.2005.05.010.

Sandhya, T.S., N.B. Prakash, A. Nagaraja, and Y.A. Nanja Reddy. 2011. Genotypic variation for silicon accumulation and effect of foliar silicic acid on growth and yield of finger millet (Eleusine coracana (L.) Gaertn.). Proc. 5th Intl. Conf. Silicon Agr. 183-184 (abstr.).

Savant, N.K., G.H. Korndörfer, L.E. Datnoff, and G.H. Snyder. 1999. Silicon nutrition and sugarcane production: A review. J. Plant Nutr. 22:18531903, doi: 10.1080/01904169909365761.

U.S. Department of Agriculture, National Agricultural Statistics Service. 2015. 2012 Census of Agriculture, Census of Horticultural Specialties (2014). Vol. 3, Special studies, Part 3. AC-12-SS-3.
Voogt, W. and C. Sonneveld. 2001. Silicon in horticultural crops grown in soilless culture, p. 115-131. In: L.E. Datnoff, G.H. Snyder, and G.H Korndörfer (eds.). Silicon in agriculture. Elsevier, Amsterdam, The Netherlands.

Wu, Q.-S., X.-Y. Wan, N. Su, Z.-J. Cheng, J.-K. Wang, C.-L. Lei, X. Zhang, L. Jiang, J.-F. Ma, and J.-M. Wan. 2006. Genetic dissection of silicon uptake ability in rice (Oryza sativa L.). Plant Sci. 171:441-448, doi: 10.1016/ j.plantsci.2006.05.001.

Yoshida, S., Y. Ohnishi, and K. Kitagishi. 1962. Chemical forms, mobility and deposition of silicon in rice plant. Soil Sci. Plant Nutr. 8:1521, doi: 10.1080/00380768.1962.10430992.

Zellner, W., J. Frantz, and S. Leisner. 2011. Silicon delays Tobacco ringspot virus systemic symptoms in Nicotiana tabacum. J. Plant Physiol. 168:1866-1869, doi: 10.1016/ j.jplph.2011.04.002.

Zhu, Y. and H. Gong. 2014. Beneficial effects of silicon on salt and drought tolerance in plants. Agron. Sustain. Dev. 34:455-472, doi: 10.1007/ s13593-013-0194-1. 


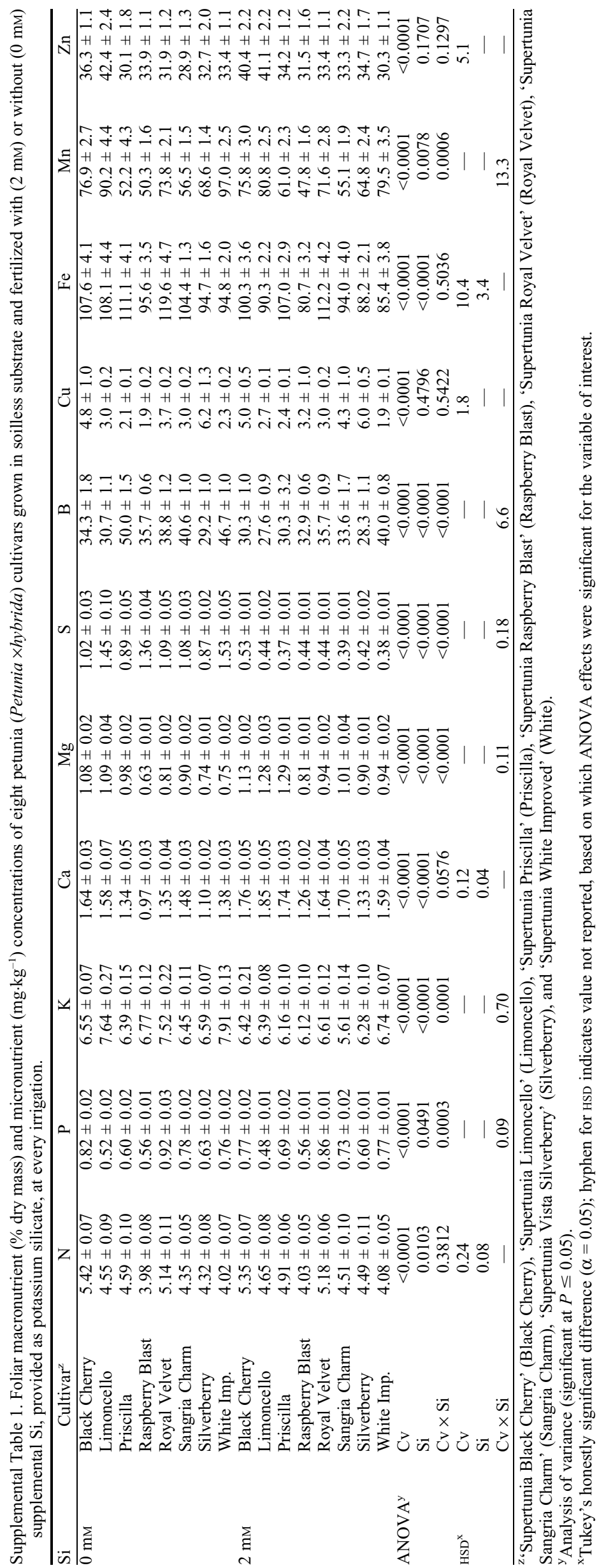

HortScience Vol. 56(3) March 2021 